\title{
PENEGAKAN HUKUM TERHADAP PELAKU TINDAK PIDANA PENGEDAR UANG PALSU DI KOTA JAMBI
}

\author{
Oleh : \\ Osriansyah* \\ Abdul Bari Azed* \\ Chairijah*
}

\begin{abstract}
ABSTRAK
Penegakan hukum bagi pelaku tindak pidana pemalsuan uang telah dilaksanakan oleh aparat penegak hukum yang terdapat dalam sistem peradilan pidana. namun dalam pelaksanaan terhadap penegakan hukum tersebut belum maksimal hal ini disebabkan masih rendahnya kesadaran hukum masyarakat.Namun masih ditemui Kendala yang dihadapi dalam upaya penegakan hukum terhadap kejahatan pemalsuan uang kertas rupiah dan pengedarannya sangat banyak, yang paling utama dan menonjol di wilayah hukum Kota Jambi yaitu sulitnya untuk menemukan pelaku pembuat uang kertas rupiah palsu yang sebenarnya karena sangat sulitnya mengumpulkan bukti-bukti yang dapat menjerat pelaku tersebut. Budaya masyarakat di Kota Jambi yang kurang sadar hukum untuk melaporkan uang palsu yang diterimanya karena takut merugi atau dituduh sebagai pelaku. Upaya yang dilakukan untuk mengatasi kendala-kendala dalam mengatasi tindak pidana pemalsuan uang dengan melaksanakan kegiatan penyuluhan/sosialisasi kepada masyarakat dengan tujuan agar masyarakat mengetahui dan mengenal ciri-ciri uang yang asli, Melakukan kerja sama yang erat antara penegak hukum dan instansi terkait lainnya, dan Memanfaatkan sarana dan prasarana yang ada secara maksimal.
\end{abstract}

Kata Kunci: Penegakan Hukum, Pelaku, Pengedar Uang Palsu

\section{A. Latar Belakang Masalah}

Uang mempunyai peran penting dalam kehidupan manusia, selain berfungsi sebagai alat pembayaran yang sah dalam suatu negara, uang juga juga merupakan simbol negara yang menjadi pemersatu. Uang juga menjadi lambang kekuasaan, dapat menjadi alat untuk memaksakan kehendak pada orang lain. Mengingat pentingnya fungsi dan kedudukan mata uang, maka setiap negara mempunyai pengaturan dan kebijakan tersendiri mengenai pengedaran uang.

Di Indonesia lembaga yang di berikan kewenangan untuk mengeluarkan dan mengatur peredaran uang adalah Bank Indonesia selaku bank sentral. Berdasarkan Undang-Undang Negara Nomor 23 Tahun 1999 tentang Bank Indonesia (selanjutnya disebut dengan UU Bank Indonesia) Pasal 2 angka (1) menyatakan : "Satuan mata uang

\footnotetext{
* Wirswasta, Alumni Program Magister Ilmu Hukum Unbari.

* Pengajar Program Magister Ilmu Hukum Unbari.

* Pengajar Program Magister Ilmu Hukum Unbari.
} 
negara Republik Indonesia adalah rupiah dengan singkatan Rp". Rupiah menjadi alat pembayaran yang sah di wilayah negara Republik Indonesia.

Sedemikian pentingnya uang menyebabkan sebagian orang berusaha untuk memiliki uang sebanyak-banyaknya, walaupun dengan cara yang melawan hukum. Wujud dari cara-cara yang melawan hukum itu dapat berupa kejahatan terhadap mata uang itu sendiri, salah satunya tindakan pemalsuan mata uang. Menurut pembentuk undang-undang perbuatan meniru atau memalsukan mata uang,uang kertas negara atau uang kertas bank itu merupakan perbuatan yang dapat menimbulkan berkurangnya kepercayaan umum terhadap mata uang kertas negara atau uang kertas bank tersebut. ${ }^{1}$

Sebenarnya pemalsuan uang, terutama uang kertas, sudah berlangsung sejak lama. Sejak awal penerbitan uang kertas, pihak berwenang selalu mencantumkan sanksi hukum terhadap para pemalsunya. Uang kertas China dari masa Kaisar Hung Wu (1368-1398), memuat ancaman pidana yang berbunyi: Barang siapa memalsu atau mengedarkan uang palsu, dikenakan hukuman.

\section{Pasal 244 KUHP}

Barangsiapa meniru atau memalsu mata uang atau uang kertas yang dikelurkan negara atau bank, dengan maksud untuk mengedarkan atau menyuruh edarkan mata uang atau uang kertas itu sebagai yang tulen dan tidak dipalsu, diancam dengan pidana penjara paling lama lima belas tahun.

Selanjutnya Pasal 245 KUHP menyatakan dengan tegas :

Barang siapa dengan sengaja mengedarkan mata uang atau uang kertas yang dikeluarkan oleh negara atau bank sebagai mata uang atau uang kertas yang tulen dan tidak dipalsu, padahal ditiru atau dipalsu olehnya sendiri, atau waktu diterimanya diketahui tidak tulen atau dipalsu, ataupun barang siapa yang menyimpan atau memasukkan ke Indonesia,mata uang dan uang kertas yang demikian, dengan maksud untuk mengedarkan atau menyuruh edarkan sebagai uang tulen dan tidak dipalsu, diancam dengan pidana penjara paling lama lima belas tahun.

Perbuatan meniru mata uang atau uang kertas itu bukan hanya dapat dilakukan oleh orang yang memang tidak mempunyai hak untuk membuat mata uang atau uang kertas

${ }^{1}$ PAF. Lamintang dan Theo Lamintang, Kejahatan Membahayakan Kepercayaan Umum Terhadap Surat, Alat Pembayaran,Alat Bukti, dan Peradilan, edisi kedua . Sinar Grafika. Jakarta, 2009. hal 162-163 
tersebut, melainkan juga dapat dilakukan oleh orang yang mendapat kepercayaan dari pemerintah untuk membuat mata uang, yakni misalnya dengan memakai bahan-bahan yang disediakan oleh pemerintah, mencetak mata uang yang jumlahnya lebih banyak dari jumlah mata uang yang ditentukan oleh pemerintah. ${ }^{2}$

Walaupun perbuatan tersebut dilakukan dengan menggunakan bahan-bahan yang memang merupakan bahan-bahan yang digunakan pemerintah untuk membuat mata uang yang sah, perbuatan tersebut juga termasuk tindak pidana pemalsuan uang karena dilakukan tanpa adanya wewenang untuk membuat atau mencetak uang tersebut dari pemerintah. Kejahatan pemalsuan uang dan pengedarannya memerlukan modal besar karena menggunakan teknologi untuk melakukannya.

Pelaku pemalsuan uang seringkali orang yang memiliki modal, berpendidikan dan berstatus sosial yang baik serta dari tingkat pergaulan yang layak. Diperlukannya teknologi yang rumit dalam melakukan kejahatan pemalsuan uang, dan pengedarannya membuat kejahatan ini biasanya tidak dilakukan seorang diri. Oleh karena itu, kejahatan pemalsuan uang dapat digolongkan kedalam kejahatan kerah putih (white collar crime) dan kejahatan yang yang dilakukan secara terorganisir (organized crime).

Selain itu, pengaturan kejahatan pemalsuan mata uang dalam Undang-Undang Nomor 3 Tahun 2004 tentang Perubahan Atas Undang-Undang Nomor 23 Tahun 1999 tentang Bank Indonesia, hanya terdapat dalam Pasal 65 dan Pasal 66 yang berkaitan dengan kewajiban menggunakan mata uang rupiah sebagai alat pembayaran yang sah.

Hal ini sesuai dengan bunyi Pasal 2

(1) Satuan mata uang negara Republik Indonesia adalah rupiah dengan singkatan Rp.

(2) Uang rupiah adalah alat pembayaran yang sah di wilayah negara Republik Indonesia.

(3) Setiap perbuatan yang menggunakan uang atau mempunyai tujuan pembayaran atau kewajiban yang harus dipenuhi dengan uang jika dilakukan di wilayah negara Republik Indonesia wajib menggunakan uang rupiah, kecuali apabila ditetapkan lain dengan Peraturan Bank Indonesia.

(4) Setiap orang atau badan yang berada di wilayah negara Republik Indonesia dilarang menolak untuk menerima uang rupiah yang penyerahannya

\footnotetext{
${ }^{2}$ Ibdi, hal .167-168
} 
dimaksudkan sebagai pembayaran atau memenuhi kewajiban yang harus dipenuhi dengan uang sebagaimana dimaksud pada ayat (3).

(5) Pengecualian sebagaimana dimaksud pada ayat (3) diberikan untuk keperluan pembayaran di tempat atau di daerah tertentu, untuk maksud pembayaran, atau untuk memenuhi kewajiban dalam valuta asing yang telah diperjanjikan secara tertulis, yang akan ditetapkan dengan Peraturan Bank Indonesia.

\section{Pasal 65}

Barang siapa dengan sengaja melakukan pelanggaran atas ketentuan sebagaimana dimaksud dalam Pasal 2 ayat (3) diancam dengan pidana kurungan sekurang-kurangnya 1 (satu) bulan dan paling lama 3 (tiga) bulan serta denda sekurang-kurangnya Rp.2.000.000,00 (dua juta rupiah) dan paling banyak Rp.6.000.000,00 (enam juta rupiah).

\section{Pasal 66}

Barang siapa dengan sengaja melakukan pelanggaran ketentuan sebagaimana dimaksud dalam Pasal 2 ayat (4) diancam dengan pidana penjara sekurangkurangnya 1 (satu) tahun dan paling lama 3 (tiga) tahun serta denda sekurangkurangnya Rp.1.000.000.000,00 (satu miliar rupiah) dan paling banyak Rp.3.000.000.000,00 (tiga miliar rupiah).

Dalam tindak pidana pemalsuan uang dan pengedarannya, untuk mengumpulkan bukti-bukti yang cukup dan menemukan tersangka- tersangkanya sangat sulit. Hal ini karena tindak pidana pemalsuan uang dan pengedarannya dilakukan secara terorganisir dan seringkali dilakukan oleh orang yang memiliki modal, berpendidikan, dan berstatus sosial yang baik serta dari tingkat pergaulan yang layak. Hal itu dapat menyebabkan kepolisian mendapatkan kesulitan dalam melakukan proses penyidikan untuk mengumpulkan buktibukti yang cukup dan menemukan tersangka-tersangka.

Fenomena yang terjadi di provinsi Jambi pada tahun 2015 berdasarkan berita Tabloit Antara Jambi, 
Uang palsu sudah ditemukan sebanyak 663 lembar dengan jumlah nominal Rp55.880.000. Lembaran uang palsu tersebut terdiri dari pecahan RP100 ribu sebanyak 453 lembar, pecahan Rp50 ribu sebanyak 202 lembar dan pecahan Rp20 ribu sebanyak delapan lembar. Penemuan uang palsu ini meningkat dari tahun 2014, yang mana dalam satu tahun hanya ditemukan 662 lembar dengan jumlah nominal Rp. 61.995.000. ${ }^{3}$

\section{B. Perumusan Masalah.}

Berdasarkan Permasalahan di atas, maka dapat dirumuskan permasalahan yang akan penulis teliti, yaitu :

1. Bagaimana Implementasi Penegakan Hukum Terhadap Pelaku Tindak Pidana Pemalsuan Uang Kertas di Kota Jambi?

2. Bagaimana kendala-kendala yang dihadapi dalam Penegakan Hukum Terhadap Pelaku Tindak Pidana Pemalsuan Uang Kertas tersebut?

3. Bagaimana upaya untuk mengatasi kendala-kendala yang dihadapi dalam Penegakan Hukum Terhadap Pelaku Tindak Pidana Pemalsuan Uang Kertas tersebut?

\section{Metode Penelitian.}

\section{Spesifikasi Penelitian}

Penelitian ini bersifat deskriptif, ${ }^{4}$ dimana penulis lebih mengutamakan kepada tujuan untuk menggambarkan fenomena yang berhubungan dengan objek yang sedang diteliti, sehingga yang dikaji adalah Penegakan Hukum Terhadap Pelaku Tindak Pidana Pemalsuan Uang Kertas di Kota Jambi.

\section{Metode Pendekatan}

Penelitian ini dilakukan dengan menggunakan pendekatan "Yuridis Empiris", yaitu melalui pengkajian peraturan perundang-undangan terkait Penegakan Hukum Terhadap Pelaku Tindak Pidana Pemalsuan Uang Kertas di Kota Jambi.

\section{Sumber Data}

Sumber data dalam penelitian skripsi ini diperoleh melalui :

a. Penelitian Kepustakaan (Library Research)

\footnotetext{
${ }^{3}$ Tabloit Antara Jambi.com, “BI, Jambi Target Peredaran Uang Palsu”, tanggal 3 Juli 2018.

${ }^{4}$ Iskandar, Metodologi Penelitian Kualitatif, Gaung Persada, Jakarta, 2009, hal. 12

${ }^{5}$ Rony Hanitijo Soemitro, Metodologi Penelitian Hukum dan Jurumetri, Ghalia Indonesia, 1994, hal. 34
} 
Penelitian ini dilakukan dengan cara mempelajari buku-buku karangan para ilmuan, ahli dan sarjana, juga terhadap peraturan perundang-undangan yang ada. Hasil dari mempelajari buku-buku dan lainnya itu diambil intisarinya, sebagai data sekunder, yang berguna dalam merumuskan dan menyusun kerangka teori ini.

\section{b. Penelitian Lapangan (Field Research)}

Sebagai tindak lanjut dari penelitian kepustakaan diatas, maka dilakukan juga penelitian lapangan, untuk mendapatkan data primer yang berguna dalam mendeskripsikan masalah dalam pembahasan tulisan ini, dengan beberapa pertanyaan kepada Responden.

Data-data primer yang diperoleh pada penelitian lapangan dikumpulkan, kemudian diolah dan diklasifikasikan kedalam bagian-bagian tertentu, untuk seterusnya dianalisis. Analisis data dilakukan secara kualitatif, yaitu dengan menelaah Penegakan Hukum Terhadap Pelaku Tindak Pidana Pemalsuan Uang Kertas di Kota Jambi kemudian hasil dari jawaban responden yang diteliti dituangkan dalam bentuk uraian yang bersifat deskriptif.

\section{Penegakan hukum terhadap pelaku tindak pidana pemalsuan uang kertas di Kota Jambi}

1. Implementasi Penegakan Hukum Terhadap Pelaku Tindak Pidana Pemalsuan Uang Kertas di Kota Jambi.

Sebelum sampai pada implementasi penegakan hukum terhadap pelaku tindak pidana pemalsuan uang kertas yang ada di Kota Jambi terlebih dahulu penulis ketengahkan pengaturan tentang sanksi pidana yang diterapkan bagi pelaku pemalsuan uang kertas.

Tindak pidana mengedarkan mata uang atau mata uang kertas palsu diatur dalam pasal-pasal dalam Kitab Undang-Undang Hukum Pidana. Maksud meniru atau memalsukan mata uang atau mata uang kertas terdapat dalam Pasal 244 Kitab Undangundang Hukum Pidana yang berbunyi:

Barang siapa meniru atau memalsukan mata uang atau uang kertas negara atau bank dengan maksud untuk mengedarkan atau menyuruh mengedarkan mata uang atau uang kertas tersebut seolah-olah asli dan tidak dipalsu, diancam dengan pidana penjara maksimum lima belas tahun. 
Maksud pelaku dalam Pasal 244 Kitab Undang-undang Hukum Pidana adalah siapa saja. Kesengajaan tersirat pada perbuatan meniru atau memalsukan. Artinya, ada kehendak dari pelaku untuk meniru, yaitu membuat sesuatu yang menyerupai uang yang berlaku, atau ada kehendak pelaku untuk memalsukan uang yang sudah ada.

Kesengajaan ini harus terkait dengan maksud si pelaku, yaitu untuk mengedarkan atau menyuruh mengedarkannya seolah-olah asli atau tidak dipalsukan. "Dengan maksud untuk mengedarkannya, berarti masih dalam pikiran (in mind) dari pelaku, belum berarti sudah beredar". Dengan demikian pengertian dengan maksud di sini selain memperkuat kesengajaannya untuk meniru atau memalsu adalah juga tujuannya yang terdekat.

Pasal 244 Kitab Undang-undang Hukum Pidana dengan tegas melarang seseorang untuk meniru atau memalsukan uang, yang dengan demikian tiada hak bagi seseorang untuk itu. "Namun bukan hal yang mustahil apabila ada seseorang yang karena kemahirannya mampu untuk meniru atau memalsu uang, asal saja tidak dimaksudkan untuk diedarkan sebagai yang asli”. Misal saja untuk dipertontonkan kepada umum bentukbentuk uang yang dipalsukan atau dalam rangka pendidikan. Hal ini perlu diperhatikan karena kita menganut hukum yang material.

Maksud meniru ialah melakukan sesuatu perbuatan mengadakan uang menyerupai yang asli. Seberapa jauh ketepatan menyerupai itu tidak dipersoalkan, asalkan uang tersebut tidak dibuat oleh pihak yang berwenang/ditugaskan untuk itu. Di Indonesia badan/lembaga yang ditugasi untuk membuat uang adalah PERUM PERURI (Perusahaan Umum Percetakan Uang Republik Indonesia). Namun apabila ada orang yang membuat uang berbeda dengan yang ada, misalnya uang kertas senilai Rp.12 atau Rp.14, tidak termasuk dalam cakupan pasal ini.

Memalsukan adalah perbuatan mengadakan perubahan pada uang yang ada baik mengenai bahannya maupun mengenai tulisannya. Misalnya bahan logamnya diganti, atau ada uang yang berbeda nilainya tetapi hampir sama bentuknya kecuali tulisan nominalnya, maka perubahan terhadap nilai nominal yang tertulis tersebut adalah pemalsuan.

Uang yang dimaksud dalam Pasal 244 Kitab Undang-undang Hukum Pidana adalah alat pembayaran yang sah pada saat pengedarannya. Ada uang yang dibuat dari logam (emas, perak, suasa, nikel, tembaga, aluminium dan sebagainya), ada pula yang dibuat dari kertas khususnya.

Uang ini dibuat oleh pemerintah atau dipercayakan kepada suatu bank. Di Indonesia pembuatan uang dipercayakan kepada Bank pemerintah, yaitu Bank Indonesia. 
Perbuatan melapisi uang logam dengan cat atau uang logam lainnya, misalnya uang perak dengan uang emas, atau uang logam dengan uang perak/emas tidak dicakup oleh Pasal 244 Kitab Undang-undang Hukum Pidana.

Dianutnya asas universalitas di bidang kejahatan tentang uang ini, maka juga termasuk peniruan, pemalsuan, pengurangan nilai uang negara lain (mata uang asing) dan bahkan oleh orang asing di wilayah Republik Indonesia, ketentuan Bab X Buku II Kitab Undang-undang Hukum Pidana dan Undang-undang Nomor 1 Tahun 1946 dapat diterapkan. Bahkan pemalsuan uang asing oleh orang asing, apabila pelakunya melarikan diri ke Indonesia dan apabila tidak terjadi "penyerahan" pelaku tersebut karena misalnya belum ada perjanjian penyerahan (uitleverings-tractaat), pelaku tersebut dapat diadili di Republik Indonesia berdasarkan pasal-pasal yang berlaku di Republik Indonesia.

Meniru atau memalsukan uang yang pernah berlaku (kini tidak berlaku lagi) tidak termasuk yang dimaksud dalam Pasal 244 Kitab Undang-undang Hukum Pidana, walaupun mungkin uang tersebut mempunyai nilai karena sejarahnya.

Perbuatan menyuruh mengedarkan dalam rumusan Pasal 244 Kitab UndangUndang Hukum Pidana apabila dikaitkan dengan ketentuan pada Pasal 55 Kitab Undangundang Hukum Pidana, ini berarti apabila yang disuruh itu tidak mengetahui tentang kepalsuan dari uang tersebut, maka baginya berlaku asas “tiada pidana tanpa kesalahan".

Selanjutnya pada Pasal 245 Kitab Undang-undang Hukum Pidana yang berbunyi sebagai berikut:

Barang siapa dengan sengaja mengedarkan mata uang atau uang kertas negara atau bank seolah-olah mata uang atau uang kertas yang asli dan tidak dipalsu, padahal telah ditiru atau dipalsu oleh dirinya sendiri, atau waktu diterima diketahui bahwa tidak asli atau dipalsu, ataupun mempunyai persediaan atau memasukkan ke Indonesia mata uang atau uang kertas yang demikian, dengan maksud untuk mengedarkan atau menyuruh mengedarkan seolah-olah asli dan tidak dipalsu, diancam dengan pidana penjara maksimal lima belas tahun.

Subyek dari pasal tersebut adalah barang siapa, yang berarti bisa setiap orang atau siapa saja. Kesengajaan dari pelaku meliputi seluruh unsurnya. Kesengajaan itu ditujukan agar dalam pengedarannya seolah-olah asli atau tidak dipalsu.

Tindakan yang dimaksud Pasal 245 Kitab Undang-undang Hukum Pidana, jika dilihat dari sudut terjadinya dapat berlanjut, yaitu: 
1. Meniru atau memalsukan mata uang atau uang kertas dan kemudian dilanjutkan dengan perbuatan mengedarkan uang tersebut, mempunyai persediaan uang seperti itu atau memasukan ke Indonesia uang seperti itu.

2. Mengetahui bahwa uang tersebut pada waktu diterimanya adalah tiruan atau palsu namun dilanjutkan dengan perbuatan mengedarkan, menyimpan atau memasukan ke Indonesia.

Perbedaan antara Pasal 244 Kitab Undang-undang Hukum Pidana dengan Pasal 245 Kitab Undang-undang Hukum Pidana, yaitu bahwa pada Pasal 244 tujuannya adalah untuk pengedarannya dan supaya dipandang oleh si penerima sebagai yang asli atau tidak dipalsu, sedangkan dalam Pasal 245, tindakannya adalah berkelanjutan yaitu setelah ditiru atau dipalsukan, lalu diedarkan dengan maksud/tujuan supaya dipandang oleh si penerima uang tersebut seolah-olah asli atau tidak dipalsu.

Ketentuan lainnya adalah Pasal 247 Kitab Undang-undang Hukum Pidana, yaitu:

Barang siapa dengan sengaja mengedarkan mata uang yang seolah-olah tidak rusak, padahal telah dikurangi sendiri nilainya atau yang ada pada waktu diterima diketahui sebagai uang yang sudah rusak, ataupun barang siapa mempunyai persediaan atau memasukkan ke Indonesia uang yang demikian itu, dengan maksud untuk mengedarkan atau menyuruh mengedarkan seolaholah uang yang tidak rusak, diancam dengan pidana penjara maksimal dua belas tahun.

Subyek serta unsur-unsur yang terdapat dalam Pasal 247 tersebut sama dengan yang terdapat pada Pasal 245. Untuk membuktikan bahwa seseorang ketika ia merima suatu mata uang atau uang kertas adalah berupa tiruan atau palsu atau suatu mata uang yang telah dikurangi nilainya adalah sulit sekali. Apabila ia menyatakan bahwa ia baru meyadari kepalsuan itu setelah beberapa lama sesudah diterimanya, kemudian ia tidak mau rugi begitu saja dan lalu mengedarkannya lagi, maka kepadanya dapat diterapkan Pasal 249 Kitab Undang-undang Hukum Pidana yang berbunyi:

Barang siapa dengan sengaja mengedarkan mata uang tiruan atau palsu, ataupun uang kertas negara atau bank tiruan atau palsu, kecuali yang telah ditentukan pada Pasal 245 dan 247, diancam dengan pidana penjara maksimal empat bulan dan dua minggu atau denda maksimal tiga ratus rupiah.

Dalam rangka penerapan Pasal 249 ini, si pelaku harus benar-benar tidak mengetahui kepalsuan tersebut ketika ia menerimanya. Jika ia tahu maka diterapkan 
ketentuan Pasal 245 atau Pasal 247, namun jika ia pada saat itu juga mengedarkan/membelanjakan uang tersebut dan benar-benar tidak mengetahui kepalsuan tersebut, maka kepadanya tidak dapat diterapkan ketentuan Pasal 245 atau Pasal 247.

Pasal 250 Kitab Undang-undang Hukum Pidana menentukan bahwa:

Barang siapa membuat atau memiliki persediaan bahan atau benda, yang diketahuinya bahwa benda itu dipergunakan untuk meniru, memalsu atau mengurangi nilai mata uang, atau untuk meniru atau memalsukan uang kertas negara atau bank, diancam dengan pidana penjara maksimal enam tahun atau pidana denda maksimal tiga ratus rupiah.

Dalam hal ini yang menonjol adalah pengetahuan (unsur sengaja) dari pelaku bahwa benda tersebut digunakan untuk meniru atau memalsu yang sekaligus merupakan penguatan unsur kesalahannya. Bahan atau benda ini dapat berupa percetakan, klise, kertas untuk uang, logam dan lain sebagainya.

Pasal 251 Kitab Undang-undang Hukum Pidana menentukan bahwa:

Barang siapa dengan sengaja, tanpa ijin dari pemerintah, mempunyai dalam persediaan atau memasukkan ke Indonesia keping-keping atau lembaran perak, baik yang sudah ada maupun yang belum ada capnya dan apabila dicap atau dicap ulang atau dikerjakan dengan suatu cara lain, akan menyerupai mata uang, sedangkan ia tidak secara nyata akan digunakan sebagai perhiasan atau tanda kenang-kenangan, diancam dengan pidana penjara maksimal satu tahun atau denda maksimal sepuluh ribu rupiah.

Pasal 251 ini dimaksudkan untuk pengetatan pengawasan terhadap peniruan atau pemalsuan mata uang. Sekiranya kepingan atau lembaran logam tersebut dibutuhkan untuk perhiasan, maka diperlukan atau harus ada ijin dari pemerintah terlebih dahulu.

Ketentuan Pasal 519 ayat (1) Kitab Undang-undang Hukum Pidana, menyebutkan bahwa:

Barang siapa membuat, menjual, menyebarkan atau mempunyai dalam persediaan atau memasukan ke Indonesia, barang cetakan, potongan logam atau benda lainya yang bentuknya menyerupai uang kertas negara atau bank, mata uang atau benda-benda yang terbuat dari emas atau perak yang telah ada 
merk pemerintah, atau perangko pos, diancam dengan pidana penjara maksimal tiga ratus rupiah.

Pasal tersebut menampung suatu perbuatan yang masih dipandang merugikan negara, akan tetapi sukar untuk menerapkan pasal-pasal pada BAB X Buku II Kitab Undang-undang Hukum Pidana. Untuk penerapan Pasal 519, tindakan pelaku tidak mesti harus dengan sengaja, akan tetapi tercakup pula suatu "perbuatan culpa" sebagaimana hal yang merupakan ciri khas suatu pelanggaran.

Untuk melihat implimentasi penegakan hukum bagi pelaku tindak pidana pemalsuan uang kertas:

Dasar pertimbangan hakim dalam menjatuhkan pidana adalah bahwa semua unsurunsur dalam ketentuan pidana yang didakwakan oleh jaksa adalah terpenuhi. Alasan pemaaf tidak dapat diberikan oleh hakim karena pertimbangannya bahwa hakim memandang perbuatan pemalsuan dan pengedaran uang palsu itu dilakukan oleh orang yang dapat bertanggugjawab, kemudian alasan pembenar tidak dapat dilakukan dalam kasus ini, hakim mempertimbangkan bahwa tindakan pemalsuan dan pengedaran uang palsu itu tetap tidak dapat dibenarkan bagaimanapun keadaannya, sehingga harus tetap mendapatkan hukuman.

Mengenai unsur-unsur yang terkandung telah dipenuhi menurut ketentuan pidana adalah pada Pasal 250, Pasal 244 dan Pasal 245 KUHP yaitu:

a. barang siapa,

b. meniru uang kertas,

c. dengan maksud untuk mengedarkan uang kertas itu seperti yang asli

d. dan tidak ditiru,

e. turut melakukan,

f. secara berlanjut.

Unsur secara berlanjut, hal ini telah terbukti dengan adanya barang bukti uang palsu yang begitu banyak, sehingga perbuatan terdakwamerupakan perbuatan yang diteruskan dan berlanjut. Tuntutan jaksa mengenai sanksinya adalah 3 (tiga) tahun penjara potong tahanan, sedangkan putusan yang dijatuhkan oleh hakim adalah 2 (dua) tahun penjara potong masa tahanan. Dasar pertimbangan hakim yang meringankan adalah: terdakwa mengaku terus terang dan tidak berbelit-belit dalam memberikan keterangan di dalam persidangan, terdakwa belum pernah dihukum, kelakuan terdakwa di masyarakat baik. 
Terkait pelaksanaan tugas dalam penegakan hukum peredaran uang palsu merincikan tugas polisi sebagai berikut:

a. Melakukan penangkapan terhadap pengedar serta mengajukan Berkas Perkara kepada Jaksa Penuntut Umum.

b. Melakukan penangkapan terhadap orang yang memalsukan atau orang yang mencetak sendiri uang palsu tersebut serta mengedarkannya. (Info diambil dari pengalaman yang tertangkap terlebih dahulu).

c. Melakukan penyitaan barang bukti berupa uang yang diduga palsu beserta alat-alat yang dipergunakan untuk membuat uang tersebut. ${ }^{6}$

Disimpulkan bahwa penegakan hukum bagi pelaku tindak pidana pemalsuan uang telah dilaksanakan oleh aparat penegak hukum yang terdapat dalam sistem peradilan pidana. namun dalam pelaksanaan terhadap penegakan hukum tersebut belum maksimal hal ini disebabkan masih rendahnya kesadaran hukum masyarakat. Hal ini dapat dilihat dari masih adanya rasa enggan warga masyarakat untuk menyampaikan laporan atau menjadi saksi atas terjadinya tindak pidana uang palsu. Sementara itu peran masyarakat sangat penting bagi penegakan hukum terkait tindak pidana pemalsuan uang.

2. Kendala-kendala yang dihadapi dalam Penegakan Hukum Terhadap Pelaku Tindak Pidana Pemalsuan Uang Kertas.

Pelaksanaan penegakan hukum khususnya terhadap peredaran uang palsu yang dilakukan oleh Polisi mempunyai beberapa permasalahan yang merupakan suatu kendala. Kendala tersebut secara umum berhubungan erat dengan perkembangan sosial budaya masyarakat yang diikuti dinamika masyarakat dengan diwarnai nuansa kebebasan euphoria, baik langsung maupun tidak langsung.

Kendala yang dihadapi tersebut antara lain:

a. Minimnya jumlah personil yang ada dibandingkan dengan luas wilayah hukum yang dibawahi oleh Polresta tidak sebanding, apalagi jika dibandingkan dengan jumlah penduduk di Kota Jambi.

${ }^{6}$ Yudha Pranata, Kepala Satuan Reserse Kriminal Polresta Jambi, wawancara tanggal 3 September 2015 
b. Anggaran kegiatan dan sarana pendukung terbatas, sehingga berpengaruh terhadap pelaksanaan kegiatan ataupun program-program menjadi kurang lancar.

c. Tindak pidana pemalsuan uang merupakan kejahatan yang terorganisir, sehingga dalam hal ini polisi kesulitan dalam mengungkap jaringan pelaku utama.

Jika dilihat dari faktor-faktor penegakan hukum maka dapat dianalisis sebagai berikut:

1. Perundang-undangan.

Untuk menjerat pelaku tindak pidana pemalsuan uang telah diatur dalam perundang-undangan, antara lain Kitab Undang-Undang Hukum Pidana dan peraturan perundang lainnya. Dalam hal tindak pidana pemalsuan uang yang pernah disidang di Pengadilan Negeri Jambi Jaksa Penuntut Umum lebih menerapkan Kitab UndangUndang Hukum Pidana ketimbang menerapkan Undang-Undang Khusus.

2. Penegak Hukum

Penegakan hukum dalam hal menangani tindak pidana pemalsuan uang adalah pihak yang termasuk didalam sistem peradilan pidana yaitu Kepolisian, Kejaksaan, Pengadilan dan Lembaga Pemasyarakatan. Dalam hal penindakan dan pengenaan sanksi bagi pelaku tindak pidana pemalsuan uang ini para aparat penegak hukum telah melakukan tugasnya sebagaimana tugas dan wewenangnya hal ini terbukti dengan adanya penangkapan, penuntutan dan pemutusan perkara di sidang Pengadilan Negeri Jambi. Ini berarti aparat penegak hukum telah bekerja sebagaimana amanat perundang-undangan yang berlaku.

3. Sarana dan Prasarana

Sarana atau fasilitas mempunyai peranan yang sangat penting di dalam penegakan hukum. Tanpa adanya sarana atau fasilitas tersebut, maka tidak mungkin penegakan hukum akan berlangsung dengan lancar dan menyerasikan peranan yang seharusnya dengan peran yang aktua. Sarana atau fasilitas tersebut antara lain mencakup tenaga manusia yang berpendidikan dan terampil, organisasi yang baik, peralatan yang memadai, keuangan yang cukup, dan seterusnya. Kurangnya sarana dan prasarana dalam pengungkapan uang palsu yang dilakukan oleh pihak Kepolisian. Sarana dan prasarana tersebut antara lain biaya, perlengkapan, dan lain-lain. 
4. Masyarakat

Penegakan hukum berasal dari masyarakat dan bertujuan untuk mencapai kedamaian di dalam masyarakat. Oleh karena itu, masyarakat dapat mempengaruhi penegakan hukum di mana peraturan hukum berlaku atau diterapkan. Bagian terpenting dari masyarakat yang menentukan penegakan hukum adalah kesadaran hukum masyarakat. Semakin tinggi tingkat kesadaran hukum masyarakat, maka akan semakin memungkinkan penegakan hukum yang baik. Dalam hal tindak pidana di Kota Jambi masih banyak masyarakat yang tidak berperan maksimal terkait penegakan hukum tindak pidana pemalsuan uang.

Peredaran uang palsu di masyarakat cukup sulit untuk diberantas. Hal ini didorong oleh perilaku masyarakat yang kurang mendukung upaya pemerintah dan penegak hukum dalam rangka mengurangi peredaran uang palsu. Kesadaran masyarakat untuk melaporkan adanya uang palsu sangat kurang. Bila mereka mendapatkan uang palsu, mereka cenderung membelanjakannya. Hal ini tidak dapat memotong mata rantai peredaran uang palsu. Masyarakat justru ikut berperan dalam mengedarkan uang palsu.

1. Budaya/Culture.

Budaya (culture) sebenarnya bersatu padu dengan masyarakat karena berkaitan dengan nilai-nilai yang tumbuh dimasyarakat. Masih banyak budaya masyarakat yang enggan melaporkan terkait pemalsuan uang kepada pihak berwajib sehingga para aparat penegak hukum pun tidak dapat menjalankan tugasnya secara maksimal yang menyebabkan sulitnya pengungkapan pelaku tindak pidana pemalsuan uang.

Dari kelima faktor penegakan hukum ini saling mempengaruhi penegakan hukum yang bermuara pada tujuan hukum sebenarnya yaitu terciptannya keadilan, kepastian hukum dan kemanfaatan hukum bagi masyarakat.

3. Upaya untuk mengatasi kendala-kendala yang dihadapi dalam Penegakan Hukum Terhadap Pelaku Tindak Pidana Pemalsuan Uang Kertas.

Seluruh kendala-kendala tersebut apabila tidak segera diatasi, akan semakin menambah beban bagi semua pihak yaitu, masyarakat dan pihak kepolisian sendiri. Upaya yang dilakukan Polresta Jambi untuk mengatasi kendala-kendala tersebut, antara lain: 
a. Menggalakkan kegiatan penugasan reserse kriminal dengan metode sasaran secara tepat.

b. Meningkatkan pemahaman dan kesadaran anggota masyarakat maupun anggota Polresta Jambi sendiri tentang pentingnya penegakan hukum tindak pidana pemalsuan uang.

c. Melakukan koordinasi dengan instansi terkait, seperti Kejaksaan, Pengadilan, dan Bank Indonesia.

d. Pengerahan personil khususnya reserse kriminal pada daerah-daerah rawan peredaran uang palsu. ${ }^{7}$

Polisilah yang pertama-tama yang harus melakukan segala daya upaya yang bersifat preventif yaitu menghindarkan terjadinya gangguan keamanan, termasuk terhadap kejahatan pemalsuan uang kertas rupiah dan pengedarannya. Polisi harus selalu siap siaga siang dan malam. Dalam tugasnya itu Polisi dianggap mempunyai indera keenam untuk mampu mencium adanya kejahatan uang palsu. Melalui indera keenam itulah Polisi diharapkan dapat dan mampu menghindarkan hal-hal yang menjadi penyebab timbulnya kejahatan uang palsu.

Langkah-langkah yang diambil Polresta Jambi dalam mengatasi kendala-kendala yang ada tersebut, tidak akan berhasil jika tidak didukung oleh semua pihak yang terkait. Dalam hal ini yang paling penting adalah kesadaran hukum dari masyarakat sangat diperlukan. Tanpa adanya kesadaran hukum dari masyarakat, seluruh upaya kegiatan yang dilakukan oleh Polresta Jambi akan sia-sia.

Lebih diuraikan upaya yang dilakukan untuk mengatasi kendala-kendala dalam mengatasi tindak pidana pemalsuan uang adalah:

1. Melaksanakan kegiatan penyuluhan/sosialisasi kepada masyarakat dengan tujuan agar masyarakat mengetahui dan mengenal ciri-ciri uang yang asli.

2. Melakukan kerja sama yang erat antara penegak hukum dan instansi terkait lainnya.

3. Memanfaatkan sarana dan prasarana yang ada secara maksimal.

\section{E. Kesimpulan}

7 Yudha Pranata, Kepala Satuan Reserse Kriminal Polresta Jambi, wawancara tanggal 3 September 2015 
Berdasarkan uraian pada bab terdahulu, maka dapat diambil beberapa kesimpulan sebagai berikut:

1. Penegakan hukum bagi pelaku tindak pidana pemalsuan uang telah dilaksanakan oleh aparat penegak hukum yang terdapat dalam sistem peradilan pidana. namun dalam pelaksanaan terhadap penegakan hukum tersebut belum maksimal hal ini disebabkan masih rendahnya kesadaran hukum masyarakat.

2. Kendala yang dihadapi dalam upaya penegakan hukum terhadap kejahatan pemalsuan uang kertas rupiah dan pengedarannya sangat banyak, yang paling utama dan menonjol di wilayah hukum Kota Jambi yaitu sulitnya untuk menemukan pelaku pembuat uang kertas rupiah palsu yang sebenarnya karena sangat sulitnya mengumpulkan bukti-bukti yang dapat menjerat pelaku tersebut. Budaya masyarakat di Kota Jambi yang kurang sadar hukum untuk melaporkan uang palsu yang diterimanya karena takut merugi atau dituduh sebagai pelaku.

3. Upaya yang dilakukan untuk mengatasi kendala-kendala dalam mengatasi tindak pidana pemalsuan uang adalah: a) Melaksanakan kegiatan penyuluhan/sosialisasi kepada masyarakat dengan tujuan agar masyarakat mengetahui dan mengenal ciriciri uang yang asli, b) Melakukan kerja sama yang erat antara penegak hukum dan instansi terkait lainnya, dan c) Memanfaatkan sarana dan prasang ada secara maksimal.

\section{F. Rekomendasi}

Berdasarkan beberapa kesimpulan diatas, maka selanjutnya penulis sampaikan beberapa saran, yaitu antara lain:

1. Agar dapat terlaksananya penegakan hukum yang maksimal terhadap kejahatan pemalsuan uang kertas rupiah dan pengedarannya ini, Pemerintah harus lebih serius lagi menanggapi kejahatan ini dengan berusaha memikirkan hal-hal yang diperlukan untuk meningkatkan kinerja dari para penegak hukum di Indonesia.

2. Agar pelaku tindak pidana pemalsuan uang tidak melakukan lagi tindak pidananya dan juga untuk mempengaruhi pelaku agar tidak mengulangi perbuatannya tersebut, membebaskan rasa bersalah pada pelaku, maka Penjatuhan pidana terhadap pelaku dilakukan untuk memperbaiki kesalahan yang diperbuat. 


\section{G. Daftar Pustaka}

PAF. Lamintang dan Theo Lamintang, Kejahatan Membahayakan Kepercayaan Umum Terhadap Surat, Alat Pembayaran,Alat Bukti, dan Peradilan,edisi kedua . Sinar Grafika. Jakarta, 2009.

Iskandar, Metodologi Penelitian Kualitatif, Gaung Persada, Jakarta, 2009

Rony Hanitijo Soemitro, Metodologi Penelitian Hukum dan Jurumetri, Ghalia Indonesia, 1994 